\title{
PHILOLOGY
}

\section{ШКОЛА «МОЛЛА НАСРЕДДИН» В КОНТЕКСТЕ ПРИНЦИПОВ ЛИТЕРАТУРНОЙ ШКОЛЫ}

\author{
Аллахверди Маммадли \\ Доктор филологических наук, профессор \\ Бакинский государственный университет, Факультет журналистики
}

DOI: https://doi.org/10.31435/rsglobal_ws/31102019/6731

\section{ARTICLE INFO}

Received: 30 August 2019

Accepted: 16 October 2019

Published: 31 October 2019

KEYWORDS

literary school, creative style, history, Azerbaijani literature, the journal "Molla Nasreddin", the beginning of the XX century, satire,

Jalil Mammadgulizadeh.

ABSTRACT

The article deals with the literary school "Molla Nasreddin" that is considered on the basis of the concrete facts and examples in the context of the principles of the literary school. The main principles of the literary school are highlighted: unity of opinions, clouseness of aesthetic ideals and novelty. The activities of the Azerbaijani satirical journal "Molla Nasreddin", the first Azerbaijani newspaper "Ekinchi", ("A ploughman"), the journal "Fuyuzat" ("Admonition") are traced and appreciated. It is emphasized that the beginning of the XX century is one of the most important stages in the history of Azerbaijani literature. The special attention is given to Jalil Mammadguluzadeh's activity as a creator of the satirical school "Molla Nasreddin" and founder of critical realism in Azerbaijan. The literary school "Molla Nasreddin" created by him is considered to be a top of satirical literature in Azerbaijan.
\end{abstract}

Citation: Аллахверди Маммадли. (2019) The School "Molla Nasreddin" in the Context of the Principles of the Literary School. World Science. 10(50), Vol.2. doi: 10.31435/rsglobal_ws/31102019/6731

Copyright: (C) 2019 Аллахверди Маммадли. This is an open-access article distributed under the terms of the Creative Commons Attribution License (CC BY). The use, distribution or reproduction in other forums is permitted, provided the original author(s) or licensor are credited and that the original publication in this journal is cited, in accordance with accepted academic practice. No use, distribution or reproduction is permitted which does not comply with these terms.

Как известно, об отдельных представителях литературных школ написано немало, однако конкретные научно-теоретические мысли о литературной школе и её принципах до сих пор не выдвигались на передний план. Литературная школа, свойственная миру искусства и, в частности, художественному слову, по своему содержанию и особенностям приобретает значимость как важнейший источник для творческого поколения.

Литературная школа - особое творческое течение; её основатель создаёт своеобразный творческий стиль, средства художественной выразительности, которые используют в различных стилистических целях творческие лица. Литературный процесс продолжается на основе творческого метода, определившегося в пределах данной литературной школы.

Литературная школа объединяет писателей на основе общности мировоззрения, литературных интересов, художественного вкуса. Этих писателей также сближает борьба за общую идею. Несомненно, у них одинаковое восприятие действительности, отношение к важнейшим событиям, времени, образ мышления. Они выражают свои эстетические идеалы определёнными стилистическими средствами.

Представители литературной школы, служащие сохранению и развитию национального бытия, мыслят одинаково с точки зрения литературных критериев и применяют одинаковый творческий стиль. Поэтому творчество этих писателей характеризуется определёнными идейнохудожественными особенностями. Каковы же эти особенности? Выбор, описание и оценка знаменательных событий времени, окружающей среды; определённая структура сюжета; типизация характера; освещение жизненных событий с помощью выразительности и языковых особенностей, создание тем самым системы эстетических ценностей и отражение положительных и отрицательных сторон жизни, общества. 
Литературная школа закладывает основу нового литературного этапа. В широком значении литературная школа - начало новой литературной эры. Литературные силы создают литературные образцы, формируют и развивают художественные, эстетические законы этой школы.

В истории человечества есть народы, воспринимающие всё своё литературное наследие как школу. Древнегреческая проза, персидский стих, японская лирика, французский роман изучаются этими народами как школа. Литературные методы также могут стать школой. Из этих литературных методов романтизм, реализм, классицизм интерпретируются как школа.

В истории азербайджанской литературы были периоды, когда преобладал и играл ведущую роль какой-либо жанр. В период преобладания жанра газель (лирическое стихотворение, состоящее обычно из семи двустиший - бейтов), ашугского стиха возникли школы газели, ашугская школа.

Литературные школы часто носят имена творцов, формирующих литературный процесс и влияющих на их развитие. В этой связи в азербайджанской литературной среде особо следует выделить в эпическо-поэтическом жанре школу Низами Гянджеви, школу Имадеддина Насими, отражающую теорию единства бытия, хуруфизм, школу мастерства Мухаммеда Физули, и по сей день сохраняющую свою актуальность, школу поэтического мастерства Моллы Панаха Вагифа. Школа драматургии Мирзы Фатали Ахундзаде, школа «Экинчи» («Сеятель», «Пахарь») (Әkinçi «Экинчи» (азерб. Әkinçi- «Сеятель», «Пахарь») - первая азербайджанская газета, издававшаяся в Баку в 1875-1877 годах. Первая газета в истории, печатавшаяся исключительно на азербайджанском языке, и первая газета в Российской империи, издававшаяся на тюркском языке. Основателем и единственным редактором газеты был азербайджанский журналист, выпускник физико-математического факультета Московского университета, Гасан-бек Зардаби, который находился под влиянием популярных идей «Народничества». Само основание «Экинчи» было революционным не только с точки зрения зарождения национальной прессы на азербайджанском языке, но и как налаживание процесса распространения информации среди народных масс. В газете также печатались научные статьи на тему биологии и медицины, а также общественного и культурного состояния мусульман Кавказа. Первый номер газеты вышел в свет 22 июля 1875 года. В настоящее время этот день отмечается в Азербайджане как День национальной прессы) (9), заложившая основы азербайджанской национальной прессы, школа «Молла Насреддин» Джалила Мамедкулизаде (Молла Насреддин (азерб. Molla Nasraddin) - азербайджанский еженедельный иллюстрированный сатирический журнал, издававшийся в Тифлисе (1906-1914, 1917), Тебризе (1921) и в Баку (1922-1931). За 25 лет было издано 748 выпусков журнала (340 - в Тифлисе, 8 - в Тебризе и 400 - в Баку). Журнал от имени мудреца Моллы Насреддина выражал идеи революции 1905-1907 годов, а также идеи рабочего движения в Закавказье. Был широко распространён по всему Ближнему, Среднему Востоку и оказывал влияние на развитие демократической печати. Журнал обличал патриархально-феодальные обычаи, призывал простой народ к борьбе за свободу, а также выступал против империализма и деспотических режимов в странах Востока) (10). По нашему мнению, принципы литературной школы - это в основном единство убеждений, близость эстетических идеалов и новизна.

Единство убеждений - осуществление деятельности на пути свободной и счастливой жизни родины, нации, развития национально-духовных ценностей.

Близость эстетических идеалов - определённое мировоззрение, одинаковый взгляд на важнейшие события времени, национальные духовные ценности.

Новизна - создание совершенно нового стиля, нового направления, нового метода в литературно-художественном и публицистическом творчестве.

Деятельность литературной школы «Молла Насреддин» полностью соответствует данным принципам. Молланасреддиновцы, дорожившие честью и славой родины, осуществлявшие самоотверженную деятельность во имя нации, боровшиеся за чистоту родного языка, руководствовались единой идеей. Представители этой литературной школы, до конца остававшиеся приверженцами идеи азербайджанства, создали ценные произведения с высоким художественным вкусом.

Нахождение таких литературных сил, отличающихся сходством художественного мастерства и сплочение их вокруг единой идеи - особенность гениальных личностей, безгранично любящих свою подину, нацию, родной язык, обладающих мощным творческим потенциалом, организаторскими способностями.

Джалил Мамедкулузаде с помощью этой школы заложил основы критического реализма, внеся тем самым новизну в азербайджанскую литературу - новый творческий стиль сатирический стиль. Авторы этого нового стиля изменили подход к теме, отношение к проблеме независимо от того, о чем или о ком идёт речь. Они разъясняли людям правду жизни, 
общественной действительности и призывали к борьбе за независимость. Таким образом, представители литературной школы «Молла Насреддин» во главе с Джалилом Мамедкулизаде осуществили исторический поворот в литературе и создавали свои произведения в совершенно иной манере, отличной от предыдущих творческих традиций.

Необходимо также, чтобы у литературной школы были умелые ученики, быстро схватывающие и в совершенстве выполняющие задания учителя. Они должны в будущем стать почётными выпускниками данной школы. У литературной школы «Молла Насреддин» есть выдающиеся представители, занимающие достойные место в азербайджанской литературе. По общему мнению исследователей, «литературная школа формируется вокруг таких образцов искусства художественного слова, которые уже в период своего создания имеют классическую сущность» $(1,122)$. Эта классическая сущность «настолько сильна, что привлекает других и становится творческим кредом целого поколения» $(2,421)$.

Конечно, любая литературная школа имеет своё начало первоначальный факт. Мастер представляет свой художественный мир, который впоследствии станет литературной школой, в совершенно иной, оригинальной форме. Для этого он мобилизует весь свой творческий потенциал, талант.

Русский критик Н. Потапов, говоря о романе всемирно известного писателя Чингиза Айтматова «И дольше века длится день», рассуждает о том, сколько времени необходимо для создания такого произведения? Если верить «паспортным» данным этого произведения, то четыре месяца... и вся жизнь Чингиза Айтматова, вся жизнь человека, мастера, обшественного деятеля $(3,147$.

Произведения, являющиеся первоначалом литературной школы, - также результат всей жизни мастера. Выдающийся учёный, исследователь литературных школ в Азербайджане профессор Мир Джалал (1908-1978) в этой связи отмечает, что в задачи научных трудов, посвященных исследованию азербайджанских литературных школ, входит не только характеристика основных стилей, прослеживание их формирования и развития, но и выявление различий между новой и старой, схоластической азербайджанской литературой, их отражение в этой специфической области идеологии» $(4,32)$. В действительности эта филологическая мысль играет ключевую роль в исследовании литературных школ. Например, если до издания журнала «Молла Насреддин〉 азербайджанской сатирической публицистики, можно сказать не было» $(5,253)$, то в данном случае эта публицистика извещает о начале монументальной школы. Однако превращение какого-либо литературного творчества в школу происходит по велению времени, в самом начале же - в контексте времени. Конечно, «в Азербайджане теоретико-эстетическая и литературнохудожественная мысль на протяжении истории - с древнейших времен по сей день - постоянно обогащается; она выдвинула целую плеяду выдающихся личностей, придала импульс развитию художественных методов и течений» $(6,7)$. XX век стал для Азербайджана как государства и нации важной исторической вехой в деле популяризации и доказательства своей идеологии, психологии и национальной культуры во всём их богатстве и самобытности. Возрождение начала XX века обеспечило не только разнообразие искусства и научно-культурное развитие. Это возрождение было обеспечено одновременно сложными противоречиями, конфликтами, общественно- историческими, политико-экономическими скачками данного периода.

Выдающийся учёный-филолог Н. Пашаева, верно указывает, что какой-либо противоречивый период, не являющийся стандартным с исторической и культурной точки зрения, часто создаёт более благоприятную почву для возрождения и определяет его развитие. Начало XX века было именно таким периодом.

Бытует мнение, что начало любого века характеризуется новыми качествами, новыми идеями. Таковым было и начало XX века. Литературный, художественный, публицистический творческий мир Азербайджана начал борьбу за новые идеи в этот период. «В начале XX века, писатели, поэты опирались на демократическую литературу; источниками для них служили драмы Мирзы Фатали Ахундова; в своих произведениях они стремились объективно отразить реальную социально- экономическую и политическую ситуацию в Азербайджане» $(4,24)$. Существовало множество идей и проблем, в авангарде которых находилось азербайджанство. Это начало, новый подход превратилось в целый мир, факт, возвысившийся до уровня школы.

Известно, что в начале XX в. Азербайджане и на Востоке существовали литературные школы, связанные лишь с именами выдающихся мастеров слова. Литературные школы Низами, Физули, Наваи, Мирзы Фатали Ахундзаде...» $(7,636)$. Следует также учесть, что столетие назад Азербайджан был колониальный страной, и в этот период в Азербайджане был и феодализм, и капитализм, т.е. историческая обстановка была представлена несколькими общественно- политическими формациями. Такая же ситуация, такое же параллельное развитие наблюдается и в культуре, искусстве, литературе. 
За 10-15 лет литература, архитектура, музыка, публицистика, литературоведение, издательство, живопись, театральное искусство прошли вековой путь развития.

В начале XX в. азербайджанская интеллигенция создала новые методы литературного творчества, заложив тем самым основы двух монументальных литературных школ - «Молла Насреддин» и «Фуйузат» («Наставление»). С прошлого века ни одно издание не превзошло в области развития сатирико- демократической печати журнал «Молла Насреддин», в романтическом же направлении - журнал «Фуйузат» (8).

Следует отметить, что в отличие от «Фуйузат» (Журнал «Фуйузат» редактировал выдающийся азербайджанский писатель, поэт, идеолог, талантливый журналист, публицист и социолог, знаток всемирной литературы Али бек Гусейнзаде (1864-1940 гг. Журнал выходил в 1906-1907 гг. на средства Гаджи Зейналабдина Таги оглы Тагиева- азербайджанского миллионера и мецената, действительного статского советника, благотворителя (1823- 1924). Журнал знакомил читателей с выдающимися представителями науки и культуры Востока и Запада. Впервые здесь были напечатаны произведения известных европейских писателей «Фауст» Гете, произведения Генриха Гейне в переводе А.Гусейнзаде. В своих стихах Али бек остро критиковал отсталость, невежество, пороки общества и, напротив, восхвалял исторических героев тюркских народов, Мустафу Кемаля Ататюрка) (11) литературная школа «Молла Насреддин» подготовила почву для создания и развития новых школа стихотворного мастерства, школа прозаического мастерства, школа публицистики, школа карикатуры.

Создатель литературной школы своим творческим стилем и жанрами выражает свою идеологию и эстетический идеал. Для этого он прежде всего создает новое учение. Для успешной деятельности литературной школы он собирает таланты и обучает их.

Создатель и главный редактор журнала «Молла Насреддин» Джалил Мамедкулизаде, сплотив вокруг себя творческие силы, служащие одной цели, творящие в одном стиле, достойно выполнил эту задачу. Школа, созданная Джалилом Мамедкулизаде, была образцовой литературной школой с высоким качеством «учебно-образовательной работы», подготовившей особо выдающиеся таланты.

На основе всего вышеизложенного можно с уверенностью сказать, что в начале XX века Джалил Мамедкулизаде был учителем всех писателей - сатириков в Азербайджане, журнал же «Молла Насреддин» - всеобъемлющим «учебным пособием» сатирической литературы и публицистики. "Молланасреддиновцы мастерски использовали различные приемы, чтобы сделать свои идеи понятными как можно большему количеству людей, и добивались этого, публикуя на азербайджанском языке остроты, фельетоны, юмор и сатиру, анекдоты, разговоры и, конечно же, карикатуры... Молланасреддиновцы стали авторами нового стиля в азербайджанской прозе и поэзии, пользуясь выразительностью родного языка. Яркие, бесстрашные произведения со страниц журнала впоследствии вошли в золотой фонд азербайджанской художественной литературы и публицистики. Они не утратили своей злободневности и поныне" (12).

Таким образом, Джалил Мамедкулизаде как создатель сатирической школы молланасреддинцов увековечил свое имя в истории азербайджанской литературы. Созданная им литературная школа «Молла Насреддин» является вершиной сатирической литературы в Азербайджане.

\section{ЛИТЕРАТУРА}

1. Журнал «Невский зритель», 1973, №28

2. Орлов В.Н. Пути судьбы. Ленинград, «Советский писатель», 1971, 744 с.

3. Потапов Н. Мир человека и человек в мире. Книга «Литература и современность». М., «Художественная литература», 1982, 454 с.

4. Мир Джалал. Литературные школы в Азербайджане (автор предисловия Тахсин Муталлимов). Баку: «Зия-Нурлан», 2004, 391 с.

5. Хабиббейли И.Джалил Мамедкулизаде: среда и современники (второе усовершенствованное издание). Нахчыван, Аджеми, 2009, 424 с.

6. Велиев Ш. Литературная школа «Фйузат», Баку: Елм, 1999, 444 с.

7. Хабиббейли И. Литературно-историческая память и современность. Баку: Нурлан, 2007, 696 с.

8. Хабиббейли И. Школа «Молла Насреддин». Газета «Азербайджан», 15 июля 2010 г., №150

9. https://ru.wikipedia.org/wiki

10. https://ru.wikipedia.org/wiki/Молла_Насреддин

11. http://www.anl.az/down/meqale/kaspi/kaspi_fevral2009/70968.htm

12. http://portal.azertag.az/ru/node/4147 